\title{
East Asian Regional Integration: The Journey Since the Failure of the EAEG
}

\author{
Farizal Razalli \\ Assistant Vice President, \\ Khazanah Nasional Berhad
}

\begin{abstract}
The failure of the East Asia Economic Group (EAEG) was more than a foreign policy failure for Malaysia. It actually shed light on the political realities in the region. The proposed EAEG excluded all the region's Western partners. Viewed as a bloc against the West and under strong pressure from Washington, all countries in the region, including Japan (supposed-to-be leader), unanimously disapproved the idea. This paper seeks to understand the contemporary development of the regional integration process in East Asia. The following two main questions are posited: 1) can linkages be established between the idea of EAEG and the later developments of East Asian regionalization process - ASEAN +3 ? 2) Can the approach of exclusive regionalization work in today's East Asia? The analysis shows that the tendency toward exclusive regionalization is rather strong. The research, however, questions the plausibility of such an exclusive regionalization given the region's everstrong interdependence with extra-regional partners across political, economic, and security domains.
\end{abstract}

Keywords : East Asia, EAEG, ASEAN, Regional Integration

\section{INTRODUCTION}

The asymmetrical power structure confronting the world after the end of the Cold War had many interesting political-economic repercussions. One single most important repercussion was the growing regionalism across the globe that seemed to put greater emphasis on region as the new political nucleus. The fast-changing global economy provided more urgency for this new political nucleus to shift from political to economic priorities. Hence, for the first time since World War 2, economics entered into the domains of high politics. This holds true especially in the case of Africa, Europe, and the Americas. New issues came to the forefront of domestic politics through regional integration, harmonization of trade policies, foreign direct and portfolio investments, and corporate governance.

East Asia, however, provided an interesting observation during this period. While the region was no stranger to the issue of regionalism, East Asia was somewhat reluctant to the idea. Hitherto, there were few significant regionalization processes, defined as strong 1 formal regional institutions, observable throughout the region (Rüland, 2000, p. 443). The

${ }^{*}$ The material presented by the author does not necessarily portray the viewpoint of the editors and the management of the Institute of Business \& Technology (BIZTEK) or Khazanah Nasional Berhad.

*Farizal Razalli : farizal.razalli@khazanah.com.my

C JMSS is published by the Institute of Business and Technology (BIZTEK).

Main Ibrahim Hydri Road, Korangi Creek, Karachi-75190, Pakistan. 
Association of Southeast Asian Nations (ASEAN) was probably the best example of regional grouping in the region. Nevertheless, the end of the Cold War had led to the growing centrifugal tendencies for deeper integration process ${ }^{2}$. The other important institution, the Asia-Pacific Economic Cooperation, (APEC) suffered from its loose institutional framework. The fear of 'western' dominance within APEC, on the one hand, and the absence of the benevolent leadership, on the other, had principally hampered APEC's potential to stand out as a successful regional integration model.

The post-Cold War East Asia then presented us with little good evidence of regional integration. This, however, does not suggest that the region completely lacked the initiative for serious regional integration. One significant initiative came about in the late 1990 from the then Malaysia's Premier, Mahathir Mohamed. During a meeting with his China's counterpart, Li Peng, Mahathir made public his idea of East Asia Economic Group better known as EAEG (this paper will hereafter use this term). Mahathir proposed for a formal economic regional block that would exclusively include all Southeast Asian nations, Japan, China, and South Korea. Such a regional economic block is comparable to that of the European Union- only Europeans and no others are allowed for entry. EAEG then would represent a truly East Asian grouping that would see the outright exclusion of the region's traditional Western partners namely Australia, New Zealand, and the United States of America. This was indeed a revolutionary proposal for the region.

\section{STATEMENT OF THE PROBLEM}

This proposal, however, failed to attract much scholarly interest. One might wonder why was the EAEG's failure treated with indifference. It appeared as if the EAEG carried little significance in the understanding of the various issues involved in realizing regional integration in the post-Cold War East Asia. Interestingly, however, the idea of exclusive regionalization did not fade away with the EAEG failure, but resurfaced half a decade later, arguably, in the form of the ASEAN + 3 (APT). The question, then, is, did the idea of EAEG influence the later developments of regional integration process in the region?

\section{ARGUMENT POSITED}

This paper departs from the starting point of the EAEG's rejection. Two rationales underlie the choice of this particular point. Firstly, EAEG was an important early attempt of a formal East Asian regionalism. It was the first serious proposal by one of the notable Statesmen which represented a exclusive trading bloc. It is therefore critical to understand such a proposal analytically in order to understand the dynamics that had motivated it. Secondly, the consequent failure of EAEG served as an important insight into the political reality of the region. Understanding the reasons behind its failure provides important lessons in explaining the future possibility of regional integration in East Asia. It was a historical event that is worth revisiting in dealing with today's issue of East Asian integration.

Given these two rationales, the research argues that EAEG's failure reflects the then and present reality of East Asia. The exclusive regionalization proposal remains unattractive to many East Asian countries especially when such an exclusivity involves the exclusion of important external partners. Although, as the subsequent paragraphs will show, the effort of forming an exclusive regional arrangement continues, the research remains cautious on the sustainability of such an effort. Any integration attempts, then, should at worst be predicated on being inclusive and open.

In further exploring this argument, the research poses the following research questions:

\subsection{What led to the rejection of the EAEG?}

a) What motivated the proposal? 
b) How justified were the motives behind the proposition of EAEG then?

c) Why was EAEG poorly received?

\subsection{What implications could be drawn from EAEG failure?}

a) Is there a perceived basis for integration?

b) Who were and are still the actors in East Asia?

c) Who, among these various actors, could be playing the leading role for the realization of an East Asian integration? - ASEAN?

\section{LITERATURE REVIEW}

To begin with, the specific analytical account of the EAEG was almost absent in the literature of East Asian regional integration. The trend in the mainstream literature has always been on concrete institutions rather than on ideas (with the exception of constructivism). More often than not, the success or failure of these institutions (or realized arrangements) serves the scholastic interest in explaining the process of regional integration. Therefore, proposal such as the EAEG was arguably ignorable as it was short of forming any concrete institution namely the arguably trading bloc that it was claimed to create. As a result of this, it created little interest to focus on such a proposal.

However, a limited few authors of East Asian regional integration consciously recalled the event of the EAEG's proposal in the late 1990. Nevertheless, many of these works mention the event in passing. Yu (2005) regards that EAEG's proposal by Mahathir as the most important initiative in East Asian regionalism. According to him, the proposal could be taken as one of the key initiatives toward East Asian regionalization. Mattli (1999) also mentions about the EAEG's proposal when he talked about the latest wave of integration in Asia. While he did not specifically suggest that the proposal was significant, he recognized the fact that the proposal came about during an important turning point in East Asian regionalism. He reckoned that the forthcoming suspension of the Uruguay Round, then, together with pressures from external (outside East Asia) community-building processes had indeed given birth to the proposal (Mattli, 1999, p. 167). Chirathivat (2005) briefly reviewed the EAEG's proposal as the emergence of new regionalism in East Asia. He attributed Mahathir's proposal to the Premier's appreciation for forming an actual East Asian Free Trade Area (Chirathivat, 2005, p. 150).

Hund and Okfen (1999) are probably among the few who had attempted to contribute to fill the gap in the literature on the EAEC (derivative of EAEG). They argue that EAEC was founded on three motives namely 1) Mahathir's look-east pragmatism, 2) the forthcoming failure of the multilateral trade agreements (with specific reference to the Uruguay Round) and the consequent strengthening of the regional trading blocs namely the European Union (EU) and the North America Free Trade Area (NAFTA), and 3) the check-and-balance mechanism against the APEC process (Hund \& Okfen, 1999).

Tanaka (2004) might have incidentally provided some analytical work on the EAEC when he attempted to trace the genesis of the ASEAN + 3. He ostensibly argued that ASEAN +3 could find its root in the EAEC. Judging from its memberships, ASEAN + 3 was similar to that proposed by Mahathir in the early 90's. Tanaka (2004), however, strongly cautioned not to emphasize on such a linkage due to other relative important factors like the Asian financial crisis that had influenced the development of ASEAN + 3 (Tanaka, 2004, pp. 7-8).

Generally, the aforementioned works clearly recognize the significance of the EAEG's (hereafter the term EAEC will be interchangeably used) proposal. It was one proposal that illustrated a regional response to the then global developments. The systemic changes that altered the bi-polar structure of the international system had given impetus for such a 
proposal to manifest itself. Therefore, many saw (and still many do) the EAEG's proposal for exclusive regional integration as one that was directed against 'somebody'. The United States of America and its western Pacific allies (Australia and New Zealand) feared that such a trading bloc would undermine their interests especially the goals already planned within APEC. More importantly, such a bloc would only encourage economic rivalry between the United States of America and Japan.

Interestingly, however, the idea of exclusive East Asian trading bloc was for instance, not totally dismissed by Japan. Petri (1993) admitted that in private some Japanese government officials and senior executives were favorably inclined to the idea of an Asian bloc as a form of regional integration (Petri, 1993, p. 45). Nordin Sopiee (1996) argued that EAEG's proposal was never directed against anybody. It was a proposal in the form of ideas of regionally binding the nations in the East Asian region (Nordin Sopiee, 1996, p. 1). It was not originally an architecture of trading bloc or institution equivalent to that of the EU or APEC. The ASEAN's consensus over the name modification from EAEG to the East Asian Economic Caucus (EAEC) in 1991, in which the original ideas of EAEG were turned into the formulation of a loose consultative body, reaffirms the fact that the ideas were never 'harmful'. Hund (2004) supported this when he saw the EAEG as a forum for East Asian states to talk about the frustrating multilateral trade liberalization and tendencies in economic-bloc formations across the globe. It formed the basis of a East Asian trading bloc. Hence, it was not clear here if such a bloc (if realized) were to be a closed trading bloc (Hund, 2004).

In summary, there is a clear gap in the literature on the EAE(G/C)'s proposal. Despite its significance as well as influence over new contemporary developments in East Asian regionalism, the proposal, however, has never been analytically approached. This, then, provides a good start for this paper to explore the proposal in more details in order to better understand the later developments in the regional integration process.

\section{THE SHOCKING IDEA OF THE 90S: REDEFINING ASIAN REGIONALISM}

Little did Li Peng know that his Malaysia's counterpart, Mahathir, would propose the idea of establishing an exclusive East Asian trading bloc. Although Beijing was taken by surprise with the idea, Chinese leadership was, fundamentally, in favor for Mahathir's proposal. Nevertheless, China, given the development at that time, was not comfortable with the exclusivity of the idea. Washington was still important to China and Beijing saw no interest to confront Washington at that time (Guohua \& Zhang, 2002). Furthermore, Beijing was puzzled by Kuala Lumpur's motive for according Japan the leading role in such a trading bloc. Did Mahathir not understand the ever-strong grudges China still has against its eastern neighbor Japan?

Mahathir had his rationale for proposing his idea to China. It could be seen as a reversed psychology diplomacy whereby a possible rejection from China on the ground of Japan's leading role would be avoided. By forwarding his proposal to China, Mahathir was implying consent-seeking for such a proposal. It reflected Mahathir's fine knowledge about the power dynamics in the region and respect for China's long aspiration to remain as the Middle Kingdom. In fact, it is argued that it was also in Mahathir's mind to include China as one of the major players in his EAEG idea.

While Japan might represent East Asia's successful economic model, China, to Mahathir, symbolizes Asian strength, through which such economic model became possible. Hence, Mahathir, through his EAEG idea offered an alternative exit to the current global trade dilemma. East Asian economies could shield themselves from the problematic global trade arrangement at that time namely the failing Uruguay Round and the US-style APEC trade liberalization. This was only possible when East Asian economies were prepared to fully 
learn the lessons and exploit resources available within the region. Unlike other regions with a fairly-high number of developing members, East Asia fortunately hosts to both some of the world's recognized advanced economies (Japan, South Korea, and Taiwan) as well as world's biggest and most promising market (China). For this reason, the less developed East Asia have less reason to find solution to their economic development difficulties from outside the region.

This went along harmoniously with Mahathir's Look East rhetoric that sees Asian miracles as an indispensable basis upon which the less developed Asian nations should base their economic development model. In Mahathir's view, his EAEG idea would allow Asian nations to strengthen cooperation among them and therefore lead them to be less dependent upon the West. With three economic powerhouses namely Japan, China, and South Korea, East Asia could stand by itself facing the dire penetration of the West capitalists.

In short, the author believes, the EAEG proposal was founded on two Mahathir's important premises (which also arguably represent the motives behind EAEG). First, intra-East Asian enhanced economic cooperation in the form of exclusive trading bloc would protect its regional members from the fatal effects of the failing global trade arrangements, and second, intra-East Asian strengthened cooperation (and eventual integration) would allow regional members to learn from and share their experiences and know-how thus celebrating and cherishing the region's success stories. Given the above premises, it remains crucial to seek for their justification. Were they at all justified? We will now turn to this issue of justification.

\section{JUSTIFYING EAEG- THE ROLE OF SYSTEMIC CHANGE}

In justifying the premises (motives), it might be worthwhile to contextualize the discussion within the contemporary systemic changes of that time. This will help us to better understand these motives; not necessarily representing the author's belief but merely representing the author's understanding of the then regional and global developments.

The downfall of the Iron Curtain in 1989 left the world in an complete uncertainty. Although it was clear that the United States would definitely assume the status of single Superpower, power vacuum existed at regional and sub-regional level. Uncertainty was only amplified by Washington's delay in announcing its new plan within the new international political structure. In brief, everybody was clueless as to how the new world structure would look like and what one could expect from it.

Observing this in East Asia, arose the question of which of the two regional Powers, Japan or China, would assume the regional hegemony status. Implicitly, however, was the U.S. factor. Whoever assumed the hegemonic status would have to deal with the United States as the global single Superpower. It was only a matter of such a deal being confrontational or peaceful.

Hence, what was clear then was the fact that the region had to deal with the U.S. factor. Such a deal would likely to be a confrontational rather than peaceful one. This was especially true in the realm of trade. The establishment of APEC in 1989 was simply one case in point. Strong U.S.-led Western-alliance in APEC does not rest well with the suspicious Asian members. The nature of APEC as a mere instrument for liberalizing Asian countries' economies at the expense of the interests of Asian economies has been confirmed on several occasions later in the 1990s' (Yu, 2005, pp. 32-33). Having to deal with the United States then would mean the regional own interests would be made secondary to that of the U.S.. Mahathir then read this as a justification for establishing a trading bloc that would keep the United States of America at the periphery. This tendency in East Asia to keep the United States of America at the periphery continues until today. Post-911 posts a good evidence to this. With Washington trying to combat terrorism and continue to put pressure 
on "evil" States like North Korea, Washington suddenly found itself not having that adequate outreach in the region that it needed to prepare for a strategic coalition with the regional member to keep the United States of America at the center (G. Rozman \& N. Rozman, 2003). Principally speaking, the need for Asian countries, according to Mahathir's line of thinking, to keep the United States out of the region then justified the establishment of the EAEG.

The important developments in Europe immediately before the end of the Cold War had also significantly influenced critical leaders like Mahathir. Already in the early 1980s there was growing discontent among members of the European Community about the lack of free trade between members. Many quarters in Europe urged for the harmonization of laws and policies among members to bring about smoother movement of goods, labor, and capital across the region. In brief, Europe was aiming for the creation of a common market. The signing of the Single European Act in 1987 was the culmination of the events that took place since the beginning of the 1980s. Like other leaders outside Europe, Mahathir saw such a development in Europe intriguingly. Asian countries might render themselves uncompetitive as trading partners for Europe.

Meanwhile, the scenario looked more worryingly in the Americas. The North American Free Trade (NAFTA) was forthcoming (NAFTA singed on December 17, 1992 and came into force in 1994) and the US participation meant that even the largest world's economy was now set to regionally 'isolate' itself ${ }^{3}$. Compounding these worries was the deadlock in the Uruguay Rounds which saw the direct confrontation between the developed and the developing countries over the agricultural subsidies, trade in services, and intellectual property rights.

There was strong reason then to believe that the world would be segmented into different regional blocs. This new form of regionalism or better known as "deep regionalism" is associated with the integration experiences in North America and Europe toward the end of the 1980's and during the 1990's. It reflects a trade diplomacy that has progressively changed its focus towards greater coordination at a institutional level, in order to respond to a growing demand for harmonization of national policies as a necessary condition for further trade integration (De Melo \& Panagariya, 1993). The logic then goes, if it were to be the trend of the day for building regional blocs, East Asia then should not lag itself behind. The need to catch up with the trend then justified the motives for the pursuit of EAEG.

I argue that justifying the establishment of EAEG on a rather larger systemic level is critical in understanding the later rejection that had eventually knocked the idea off. Besides, it is more appropriate to rationalize Mahathir's proposition within a context and environment where EAEG was proposed to take off. The reason being that EAEG, if established, was meant to deal with the challenges and opportunities of the system within which it was formulated and thought off. To say the least, given the systemic condition of that time, EAEG proposal appealed to the contemporary logic and was thus justifiable within the regional framework. Having said that however why then was the proposal refused? The next part explores this question in further details.

\section{THE BIG 'NO' FOR EAEG- THE REALITY OF THE REGIONAL POLITICS}

Would it have made a difference had Mahathir presented his idea of establishing the EAEG to another party? The answer to this would be no. It was not about whom the idea should have been presented to, but rather what the idea was all about. In this respect, I part company with many others that it was not about building a trading bloc but it was about excluding (and 'including' as demonstrated later) certain important actor(s). Had the EAEG included the United States (and thus the inclusion of the U.S. strong allies Australia and 
New Zealand), there would be a possibility for the idea to be thought over seriously ${ }^{4}$.

It appeared then that Mahathir failed to understand the logic of the larger regional politics. I, however, would cautiously go along with this assumption. Given Mahathir's vast experiences in dealing with regional politics during his one decade in office, I would argue that Mahathir was experimenting with his regional counterparts. In fact, I would not be surprised if Mahathir knew it very well in advance that his idea would be unanimously rejected. It served to be like a litmus-test to investigate the compatibility of regional integration with the regional politics. Having said that, however, it is argued that Mahathir, in the course of formulating his idea, did not conform, at least, to the ASEAN's tradition of informal brainstorming of ideas. Hence, Mahathir hurt his ASEAN colleagues by not talking to them first before submitting his idea to ASEAN's most immediate Northeast Asian neighbors 5 .

However, this 'emotional injury' was merely the cosmetic part of the larger explanation for the EAEG rejection. As I argue at the beginning of this part, it was the US-factor that dominated the whole issue. The US opposition to the idea was critical and served to be like a warning to the region. As mentioned in the earlier part of the analysis, the collapse of the Soviet Union in 1989 left many uncertainties that could lead to many possibilities. However, one certainty is the fact that the United States would emerge as a single dominant Superpower. A heavy unilateral political structure then is likely to proceed.

Mahathir's diplomatic calculation that such a possible unilateralism would create a sense of insecurity among nations in the region was, in this case, inaccurate. The reason could probably arise from the fact that Mahathir's eastern-oriented pragmatism and therefore anti-western philosophy was not equally shared across the region. Even Japan, the main protagonist in the EAEG proposal, unfortunately distanced itself from Mahathir's antiwestern philosophy. Japan's ambivalent attitude toward EAEG was partly explained by the fact that it's foreign policy was very much constrained by the U.S. policy. The legacy of the Cold War left Japan dependent upon the United States of America and leaving no rooms for Japan undertaking autonomy in regional affairs (Baogang, 2004). Tokyo respected Kuala Lumpur's Look East rhetoric and in many ways thanked the latter for giving it some sense of prestige through such a rhetoric-cum-policy. Nevertheless, Tokyo could not identify itself with Kuala Lumpur's strong anti-western philosophy. Confrontations with the West especially with Washington would prove to be so costly. Already Japan had bitter fight over trade issues at the turn of the 90's. Worsening this fight in the post-Cold War era could only mean a major political mistake for Tokyo. Living with so many uncertainties made Tokyo ever more dependent upon its Western allies especially Washington with regard to safe-guarding its security interests vis-à-vis potential hostilities from its immediate suspicious neighbors (North Korea and China).

With regard to ASEAN, while many leaders recognized the need not to align too close with the United States, they also recognized the need not to create confrontations with Washington. Jakarta and Singapore, for instance, had and still have an array of bilateral arrangements especially in the realm of economics, politics, and security. Despite the occasional hiccups in the bilateral relations, Jakarta (and to a certain extent Singapore and Thailand) regard the United States of America as indispensable factor in their economy. The latter was and is a number one trading partner of many ASEAN members (including Malaysia!) and this fact indirectly implies that risking their sound economic relations for the sake of being purely politically (with regard to foreign policy formulation) independent would be the last option to make (Korhonen, 1998, pp. 178-179). And Mahathir himself knew this. Nevertheless, he was simply banking his chance on the current systemic change, which of course had miserably frustrated him.

Here comes then the issue of how independent the region was vis-à-vis the US interest. The symbolic gesture of Mahathir forwarding his proposal first to China actually in a way reflects this dependency of the region on the United States. It speaks of Mahathir's fine 
knowledge about the regional constraints. With almost all East Asian nations drafting their (foreign) policies that attuned to the US-factor, China, being the symbol of strength in the region, was the best bet for political endorsement of the EAEG idea. Being one of the major Powers in the world politics, Mahathir was counting more on Beijing for "political" clearance of his proposal.

Beijing, however, added another stumbling factor to the realization of the EAEG- the Japan factor. Whether or not Mahathir had carefully thought about this factor is, in this case, of secondary importance. Of more importance is the fact that it represents the reality of the regional politics. If the litmus-test argument were to hold true, then Mahathir's experiment should comfortably confirm the existing state of difficult relations between the Northeast Asian nations. In fact South Korea's rejection was also based on the same ground. In Beijing's (also Seoul's) point of view, according Japan with the leading role in the EAEG would only increase Japan's political mileage. This neither Beijing nor Seoul (also many ASEAN members) would want to see happen.

\section{THE FAILURE OF THE EAEG- LESSONS TO BE LEARNT}

It may sound pessimistic to argue that the rejection of EAEG has so huge an impact on the future of East Asian integration. Nevertheless, this work regrettably subscribes to this argument. To many, the EAEG rejection was just another foreign policy failure for Mahathir specifically and Malaysia generally. However, viewing it from an implicit standpoint, it reflects a number of key issues that (were) are inherent in the regional political structure of East Asia.

There are three major observations from this rejection. They all concern the three major regional actors namely ASEAN, China (and South Korea), and Japan. We will turn to each of these actors in the following paragraphs.

Despite concern over the approach through which the EAEG was proposed, ASEAN's main rejection to the idea was due to individual interests of the members. Economic interests ranked high in the foreign policy of most of the members. What this means is that any attempt at risking these economic interests would be treated as a threat and thus would be rejected. The US-factor was and still central in the economy of all ASEAN members. Interestingly enough Malaysia herself recorded trade surplus with the United States for the most part of the 1980s. The same story goes with Thailand, Singapore, and Indonesia. It is imaginable, then, if Washington were to reduce its commercial and trade affairs with the region, not only would this surplus turn deficit, ASEAN's competitiveness would be adversely affected as the US pull-out would mean a huge dent across economic sectors hence paralyzing the industrial capabilities as well as investment growth. To some ASEAN members like Indonesia, Singapore, and the Philippines, the adverse effects go further to affect other concerns namely security. Arguably, the United States had begun to leave the sub-region after the Vietnam War. Washington's military engagement in the region was limited to exclusive bilateral security relationships with a few States in the region namely Singapore, the Philippines, Thailand, and Indonesia. Nevertheless, these security relationships turned out to increase the US coercive power vis-à-vis the Southeast Asian States as the latter became more and more dependent for military aid and latest technical know-how. This meant that certain latitude of security arrangements would be expected to be reviewed, and in the worst-case scenario canceled altogether (in fact, the United States used this leverage to warn Japan against participating in the EAEG) (Zhao, 1998). Such a punishment could be harsh and damaging to some ASEAN members.

This is the crude reality in ASEAN. However, it should be framed within a certain rationale. ASEAN was and is still never a reliable institution to depend upon in terms of security. Its loose binding mechanism guarantees no reliable protection to members in time of emergency. Given the period after 1989 where localized crisis as the legacy of the Cold 
War might break out anywhere and anytime, security guarantee especially among small nations like Singapore and Brunei was crucial. Hence, there was a need for the occasional presence of outside Power to help monitor the situation. The United States of America, then, was still the best candidate to perform this task. In short, it is inherently accepted that including rather than excluding the United States of America is the best policy to go in almost all spheres. The US factor was, is, and will remain entrenched in the heart of ASEAN's members' policy formulation process.

China presents us with another unique dilemma in the East Asian region. Beijing, like any other nations, was struggling hard to make sense of the future after the downfall of the Soviet Union. While its affinity with the Kremlin faded out since the late 70's, the downfall of the Iron Curtain meant that communism had begun to fall apart. The need to maintain the Chinese communism then became the primary agenda for Beijing. Hence, Beijing would be cautious in accepting proposition for regional integration and alike out of fear that such a proposition might render Chinese ideology irrelevant thus rupturing the entire system it had been defending for. Besides, Chinese leaders and political elites (to an extent its academics) were more pre-occupied with the issue of nationalism in order to maintain China's prestige and dominance regionally and globally (G. Rozman, 1998 \& Wang, 1997). This partly explains why China viewed Japan's leading role in the EAEG proposal unacceptable. Notwithstanding the bitter history relations (the same applies to South Korea), China fears that Japan's increased political leverage would render itself to the second Power position in the region. Although it reluctantly accepted the fact of Japanese economic might, it could not accept Japan as more politically superior. This need to contain Japan constructs another important reality in the region. Integration then, if it ever takes place, might need to overcome this reality. It is not an exaggeration to argue that until and unless China and Japan successfully do away (or at least reduce) with their suspicions for each other and begin to see each other as potential good neighbor rather than rival, successful regional integration will emain remote.

Japan, on the other hand, was never enthusiastic about integrating the entire East Asia. Two plausible explanations are the US factor and the Japanese perception about its East Asian neighbors. While the former reality still prevails until today, the latter has in the recent years gradually changed. Nevertheless, the big dilemma remains for Japan to assume an active role in the East Asian integration process. It has to overcome many East Asian nations' suspicions about its increase political strength ${ }^{6}$. Tokyo might need to sort out burning issues with its neighbors especially China relating to historical baggage. Time is of essence here. Therefore, it was very uncertain then that Japan could afford to engage in a formal integration process in the immediate years to come. However, as the next section will show, Japan's renewed stance on regional integration following the Asian financial crisis might bring new hope for materializing the regional integration project

\section{EAST ASIAN INTEGRATION: FROM THE PAST INTO THE FUTURE}

The paper continues the analysis on the East Asian regional integration project with the developments after the failure of the EAEG. The major emphasis is given to the development of ASEAN + 3 into a promising institutional framework for regional integration. The controversial genesis of ASEAN +3 and its connection to the EAEG re-highlights the theme of exclusive East Asia-only regionalization. The analysis, then, evaluates the feasibility of this exclusive regionalization and provides some implications of such an approach toward regionalization. The final analysis shows that East Asian regionalization is better off when it remains inclusive rather than exclusive.

\subsection{The Asian Financial Crisis: Rejuvenating the Idea of EAEG}

The failure of EAEG to take off was controversially a complete failure. As the previous 
analysis pointed out, the idea did fundamentally appeal to some in the region. In fact, ASEAN through the mediation of Jakarta dropped the proposal only to replace it later with another loosely consultative body called the East Asian Economic Caucus (EAEC) (Hoon \& Robert, 1991).

The idea of the EAEG (or of the possibility of pursuing an exclusive East Asia-only regionalization) was, in effect, very much alive throughout the 1990s. One of the factors that had kept this idea alive was the concern over the Western-dominance in APEC, the single-most important inter-continental multilateral forum in which many East Asian countries are members to. The increasing US influence in the forum especially after the Seattle Summit that translated into further push for trade liberalization had raised serious concerns across East Asia. Never had this concern been so intense than it was in the aftermath of the Asian financial crisis in 1997.

There was however no single best narrative on the Asian financial crisis. While one could consensually agree on the existence and consequences of the crisis, one is uncertain about the causes, scope, and resolution of such a region-wide financial collapse ${ }^{7}$. Throughout the 1990s, countries in the region recorded high GDP growths with an average of $6-8 \%$ rate thanks to the massive inflows of FDIs in capital that consequently led to the run-up in assets' prices. These FDIs however were hot money that tried to maximize their returns on short-term basis by taking advantage of the high interest rates policy these East Asian countries (especially the Southeast Asia's rapidly developing economies) offered. Nevertheless, the then global economic developments combined with 'bad' macro-economic policies proved to be an expensive cost for East Asian economies ${ }^{8}$. In the middle of 1997, Thailand saw the worst devaluation of its Baht and thus paralyzed its financial sector especially when many private firms began to default on their foreign-denominated (mostly US-denominated) debts. Situation in Thailand had created a domino-effect across the region which saw Indonesia's and South Korea's economy falling prey to the same fate as Thailand.

This chapter is however more concerned with the subsequent implications of the Asian financial crisis. In the wake of the crisis, the crisis-hit East Asian countries were expecting the APEC's miracle help. The theme on Asian financial crisis was first brought to the table during the 9th APEC Summit in Vancouver, Canada. East Asian countries especially Thailand, Indonesia, and South Korea were looking forward to receiving urgent assistance from other developed APEC members especially the United States to deal with the then ever-worsening crisis that threatened not only economic development but also political and social cohesion.

Nevertheless, the outcome of the summit was truly frustrating for the crisis-hit countries. Not only that the proposed regional financial cooperation scheme was at best rhetorical, the deep conflict of interests between the United States and Asian countries were openly revealed. It was at this point clear that the United States was never interested and sincere in helping these Asian countries out of the crisis. Instead, another 'outsider', the International Monetary Fund (IMF), was given the task to help these crisis-hit countries. The saga took a more dramatic turn when the noble proposal from Japan, that reflected Asian solidarity, to establish an Asian Monetary Fund was strongly rejected (Yu, 2005, pp. 32:38). This simply reinforced the perception that there was a urgent need for a specific regional cooperative body to deal with the crisis. What is interesting, however, is that fact that this specific regional cooperation was thought off within the framework of an Asia-only regional cooperation.

\subsection{ASEAN + 3: The 'Geist' of EAEG?}

Webber (2003) noted that Prime Minister Mahathir had failed, only in practice, to found his proposal of EAEG (Webber, 2003, p. 142). This was in line with Alatas's (2000) 
observation that by the end of the 1990s, the creation of the APT, which he argues effectively as the EAEG, had only reinforced the idea of exclusive regionalization in the region (Alatas, 2000, p. 8). By this the work meant to say that the idea behind the APT was to try to bring together only ASEAN and its three Northeast Asian neighbors namely Japan, China, and South Korea into a single forum and eventually an institution that is comparable to other institutions like the EU. In short, the work's earlier observation that the exclusive regionalization idea was very much alive throughout the 1990s holds true. The question, however, would this idea ever be successfully implemented?

Only to reemphasize at this point, while this work observes the idea of Asia-only regionalization, it cautiously assumes the connection between the APT and the EAEG (or at least the renewed version of EAEC framework). Undoubtedly, the APT was driven by ASEAN's initiative just like the EAEG was proposed by an ASEAN leader. In fact, as the first APT Summit was held in December 1997 in Kuala Lumpur during the ASEAN Leaders' Summit, it seems logical to conclude that Mahathir's EAEG idea was beginning to regain its currency. Nevertheless, until the analysis of some of the significant historical events is put forth, one should at best be critical in jumping to such a conclusion.

\subsection{The ASEM Process}

This work, once again, emphasizes the role of systemic changes that stimulated the events within the region including the creation of the initial APT process. The idea of bringing together ASEAN and the three Northeastern countries, since the failure of the EAEG, was already resurfacing in mid-1990s when the Asia Europe Meeting (ASEM) process began to take off (Tanaka, 2004, p. 8; Yeo, 2000, p. 143). The inception of ASEM with its first meeting held in 1996 in Bangkok had given new stimulus to the regionalization process in East Asia. Owing to the hard work of Singapore with the strong support of France, ASEM tries to deepen dialogue and cooperation across all domains namely politics, economics, security, culture, and education. Implicitly, ASEM process would bring closer the East Asian states and the European states thus accord the East Asian states with the strategic partner status of the EU (Leong, 1999, p. 19). East Asian states, on the other hand, were beginning to engage themselves with the process of strengthening their identity as a collective group. The Japanese finance minister Miyazawa regarded the talks that the East Asian states had with Europe helped East Asia to build its own identity (Financial Times, January 16, 2001).

At this point, the author argues that one should not underestimate the role of the EU in the ASEM process. Despite clear differences (which include values like human rights and democracy), Europe (with the exclusion of Great Britain) appears more neutral in its approach toward Asia. The historical relationships (mainly through the colonial experiences and thus lessons from such experiences) could serve to be a strong point for trustful relations that will eventually lead to the enrichment of East Asian experience in enhancing its regional integration project. The deepening of the ASEM process, the author argues, might even help lead to the possible rapprochement of China, Japan, and South Korea. However, this requires the long-term strategic partnership between East Asian and Europe, possibly beyond the current framework of ASEM.

\subsection{Crisis of APEC}

The stagnancy of the APEC process, due to internal conflicts over the pursuit of trade liberalization at the expense of the promotion of economic and technical cooperation since the Seattle summit (and consequently the Bogor Declaration), equally stimulated the idea of East Asian exclusive regionalization. Arguably, the change in the US attitude in the mid-1990s toward the region vis-à-vis the formation of regional groupings had consequently seen the change in Japan's foreign policy. With Clinton just surviving his second term in the White House, the administration, then, pre-occupied itself with domestic pressures 
especially in trying to revitalize the economy. At the same time, the United States, being extremely disappointed with the pace at which the APEC process progressed after the Bogor and Osaka summit, was seemingly unwilling to provide its continued leadership in APEC. The absence of a undisputed leadership is the main paralysis in APEC. In this regard, I contest those who argue that the United States did play a hegemonic role in APEC. Yu (2005), for instance, confused between being a leader and a 'hegemonic' leader. Being a leader does not necessarily make one a 'hegemonic' leader (Yu, 2005, p. 34). The United States is undoubtedly playing a leading role (as it showed at the Seattle summit). Nevertheless, this leading role was insufficient as it does not qualify itself as a hegemon. This is where the problem lies as to achieve the undisputed leadership, a leading state has to acquire this hegemonic role.

It was, then, observable that Washington remained silent on ASEM in 1996 and later on the APT in 1997. Such an attitude allowed Japan to independently execute its foreign policy vis-à-vis the region and this resulted in Japan's participation in ASEM and APT. It is clear, then, at least at this juncture that the post-EAEG initiatives for the gathering of ASEAN and the three Northeastern countries were already taking place prior to the Asian financial crisis. As the East Asian countries felt disillusioned with the US-dominated APEC process, it was just a matter of time before these countries look for an alternative action. The crisis, then, arguably expedited (rather than primarily caused) the institutionalization of the APT process 9 .

\subsection{The 'Outsider'- The IMF}

The role of the IMF in propelling the closer East Asian cooperation was rather instrumental. Nevertheless, it served as an alarm that woke the East Asian countries up from their long dream. In brief, the IMF's sudden appearance in the scene of the Asian financial crisis was a blessing in disguise for the region.

The IMF came at the United States's invitation. Washington strongly asserted that the Asian financial crisis was purely a balance of payment (BoP) problem. Hence, the IMF was the most appropriate candidate to deal with the crisis. (Un)Fortunately, some key East Asian countries saw eye to eye with Washington and therefore chorused the IMF's leading role in managing the crisis. Nevertheless, just like in other regions where the IMF undertook its mission, the Fund simply aggravated the crisis rather than alleviating it. The Fund's orthodox prescriptions, far from correcting the problem of massive capital outflows, had only resulted in political and social turmoil (Stiglitz, 2003, p. 217).

The worsening situation had made these East Asian states realized that their dependence upon the West especially upon the United States had only made them worse off. They felt betrayed as the United States, according to them, were not loyal as much as they (the East Asian countries) had been to the United States. East Asian countries saw how the United States would rush in "personally" to help bail out Russia and Brazil during similar crises. On the contrary, the United States just stood by (and let the IMF) and watched Asia destroyed (Financial Times, June 30, 2000). Hence the presence of the IMF had reinforced the determination of the East Asian (especially the Southeast Asian) countries to come together and form closer cooperation with their Northeast Asian neighbors ${ }^{10}$. It is, however, critical to note at this point that the literature on the reluctance of the United States to come to the East Asian countries' defense in the wake of the crisis is insufficient. Most of the works emphasize on the biased interest-based argument. The work, then, argue that the same interest-based argument can be used to suggest that since the late 1980s and throughout the 1990s, the US economic interests in the region had declined proportionately to that of Japan. The United States recorded deficit in its trade balance with many Asian countries namely China (refer to table 2 in appendix B). During most of this period, especially following the Plaza Accord, Japan became the leading FDI source in the region. In fact this was confirmed on many occasions by statistics namely that of the ADB (ADB, June 
1, 2007). Hence, with declining interests on the part of Washington, it reduced the incentive to mobilize its own resources (also contracting resources due to domestic recovery) to help the East Asian countries. Speculative as it may seem, there is, then, a need to conduct empirical study on this subject.

\subsection{The Alternative Way}

$\mathrm{Yu}$ (2005) argued that the creation of the APT marked the new wave of Asian regionalism (Yu, 2005, pp. 39-40). According to him, two most important concerns with regard to this new wave of Asian regionalism are its goal and its major players. Bergsten (1995) and $\mathrm{Yu}$ (2005) observed that the initiative toward realizing East Asia-only regionalization was going strong on both sides- ASEAN and the three Northeast Asian countries (Bergsten, 1995, pp. 13-25 \& Yu, 2005, p. 39). It is, however, the latest development in the Northeast Asia $^{11}$ that is rather striking (Yu, 2005, p. 39).

Undoubtedly, the APT process has gone beyond what many critics had expected. As mentioned earlier, if one were to judge from the first meeting in 1997, one might conclude that the APT will just be another "talk shop" for both ASEAN and its three Northeast Asian neighbors. Nevertheless, the second meeting in 1998 gave promising future to the APT process. First, it was during the 1998 meeting in Vietnam when the APT leaders agreed to institutionalize the meeting thus confirming the regularization of the summit process. Equally important were the Kim Dae Jung's proposal to form the East Asia Vision Group (EAVG) and Hu Jintao's proposal to convene a meeting for financial experts (Tanaka, 2004, p. 8). The APT continued to produce positive results when the leaders jointly issued a Joint-Statement on East Asians cooperation that reinforced continued commitment to pursue closer regional cooperation. This had, in the following year, led to the adoption of the Chiang Mai Initiative which established the currency swap arrangement between the APT member countries ${ }^{12}$. The 2000 meeting also pledged to promote a regional cooperative mechanism through the formation of the East Asia Study Group ${ }^{13}$ which came into existence in the first half of 2001 (ASEAN Secretariat, June 30, 2007).

The APT attempted a more substantial economic-based integration in 2004 when the leaders seriously considered developing the Asian Bond Market. The APT Economic Ministers were also tasked to conduct a feasibility study on the realization of the East Asia Free Trade Area (EAFTA). A more holistic attempt for regional integration was the proposition of the East Asia Summit (EAS) where Japan hosted the APT Foreign Ministers Meeting to thoroughly discuss the EAS that would eventually pave the way for the realization of the East Asian Community (ASEAN Secretariat, June 27, 2007).

\section{THE APT PROCESS: AWAITS A ROSY JOURNEY AHEAD?}

Given the progress made so far, it is not an exaggeration to say that the APT is in good shape to achieve its ultimate goal of East Asian integration. However, being in good shape does not necessarily mean being able to perform. One may look healthy (in shape) but it does not mean that one is necessarily fit to run and win the race. It is an issue of capacity and resources available at the APT's disposal. In particular, given the strong external pressures that had brought about the APT process, it is crucial to explore the possibility of the APT's success (survival) through an exclusive Asia-only regionalization.

\subsection{Interpreting the Intra-Apt Trade Reality}

The intra-APT trade accounts for about 51\% (IMF's 2000 estimate) of the APT's overall trade. The volume of cross-border exchange in East Asia, while surpassing that in the NAFTA, is, however, lower than that in the APEC and the EU (The Economist, August 26, 2000, p. 71). This can only mean one thing for the prospect of the East Asian integration. The regional countries still lack the policy initiative to prioritize intra-regional trade. A 
brief look at the export and import partners of some of the regional countries shows clearly that the region is still very much dependent upon the United States. Of the three developed ASEAN economies namely Malaysia, Singapore, and Thailand, only Thailand shows the absence of the United States in its import-export matrix for the top-two trading partners (refer to table 1 in appendix A). With regard to the Plus Three countries, the United States remain to be Japan's, China's, and South Korea's major trading partners. Webber (2003) observed that while the East Asian countries' dependence on the American market is still strong, such a trend will decline (Webber, 2003, p. 147). The question is, however, will this decline be matched with by an increase in intra-APT trade in years to come? The main point to note here is not whether East Asian countries will be less dependent upon extraregional partners. Instead, one has to explicate how would this dependency be reduced and the conditions that make it possible.

\subsection{Rational Monetary Policy}

The Chiang Mai Initiative that produced the currency swap arrangement emphasized the importance the region places on monetary cooperation. Such an importance might have been the direct result of the bitter financial crisis that took the entire region by surprise. Nevertheless, a more critical analysis will lead one to argue for the precedence of the globalization of financial market over the localized crisis. The Asian financial crisis had as much to do with the irresponsible bullish attitudes of the international investors and speculators as the 'bad' macro-economic policies. Hence while monetary cooperation may provide a shield from the potential future of similar financial crisis, it is, however, no guarantee. It is a question of East Asian bargaining power in the larger international financial community namely in the Bretton Woods institutions. The Asian financial crisis, while it was recognized as significant in the modern history of international finance, it did not, however, change much of the current international financial structure. The reason being that the domineering West were those who did the retrospective analysis of the crisis without much participation from those affected by the crisis (Stiglitz, 2003, p. 222; Moon, Rhee \& Yoon, 2005, p. 138). The less influential East Asian countries, then, stand disadvantage vis-à-vis the international financial community in expressing their concerns and needs. This calls for an inclusion (or integration) of the regional monetary cooperation scheme into the larger framework of the international financial structure. The East Asian monetary system, for instance, might have to reflect the monetary reality of the region. As clearly shown by the currency swap arrangement, the US dollar remains central against which such swap arrangement operates, at least among the APT's ASEAN members. Hence, the tendency toward establishing an exclusive Asia Monetary System (AMS) that pursues exclusively Asia-only intermediate exchange rate arrangement should be cautioned. Although it is one of the many proposals, the exclusive AMS should be handled with care. First, such a proposal was purely ambitious given the present level of East Asian regionalization process. Second, it undermines some important crude realities in the region namely the economic disparities between the regional countries, politicoideological differences, as well as diverse national interests across the region (Moon, Rhee \& Yoon, 2005, pp. 134-152). An Asian currency basket with the exclusion of world's hard currency namely the US dollar (and to an extent the Euro) is problematic, if not implausible.

To begin with, the choice of a currency basket should reflect a country's significant trading partners. In this regard, East Asian countries need to reflect on who constitute their most significant trading partners. At present, as proven by the intra-regional trade figures, the region still significantly trade with partners from outside the region namely the United States, the EU, and Canada. It is inadvisable then for the region to ignore this fact and establish a Asia-only currency basket. Moon's (2005) argument that the inclusion of outside currencies would only make concerted interventions impossible is, in this case, not at all convincing. Although Moon (2005) might be correct to say that in time of crisis one could not rely on these 'outsiders' to sacrifice their own economic policy goals in favor of East Asian countries, this argument is at best speculative (Moon, Rhee \& Yoon, 2005, p. 146). 
In today's interdependence, one hardly turns blind eyes to even a small change in every corner of the globe. With interests everywhere, all countries will do whatever they can to ensure that they are better off and that includes providing required and timely assistance to respective regions or countries, at least to protect their own interests. It then requires the East Asian countries to strategically (smartly) positioned themselves as to increase the stake-holding of these outsiders within the region to the extent that their interests are deeply sewn in the region. This work, however, does not either suggest that the outside currencies are to assume the dominant role in the currency basket. What is important is that the creation of an open Asian currency basket is complemented with closer strategic partnership across all domains with the extra-regional countries. It is like according these extra-regional partners with stakes; one would not easily risk loosing his stakes and therefore committing them to be accountable for the region's prosperity and success.

\subsection{The Absent Leader}

Just as much as the EAEG failed due to the absence (due to refusal) of a benevolent leadership, so too would the APT. It is not at all clear who is assuming the undisputed leadership role in the APT. Clearly, all the four major actors namely Japan, China, South Korea, and ASEAN are the potentials. Although Japan and (or) China may make better candidates. As the previous analysis on the EAEG pointed out, the historical past that resulted in deep suspicion for each other still bedevils the Sino-Japanese relationship. In fact, the current rates of economic growth (hence the growth of military prowess) in China only suggests that China will eclipse Japan in terms of the capacity for regional leadership in East Asia (Zhang, November 26, 2000). The APT then is likely to be plagued by a constellation of dueling would-be hegemons. These two would-be hegemons are constantly seeing themselves as potential military adversaries (Webber, 1999, p. 2). South Korea, on the other hand, might ideally fill up this leadership vacancy. Nevertheless, it falls short of the capacity to mobilize its leadership resources given its size and dependence upon Japan and China. Seoul may not want to assert too much of independent foreign policy initiative that might suggest its open rivalry with China and Japan. Equally problematic for South Korea is her strong alignment with the United States (Yu, 2005, p. 36). Beijing (to a certain extent other countries in the region), then, will remain cautious about the prospect of South Korea assuming the leading role.

The issue of leadership in the APT is crucial especially in the coming years when the process matures itself and thus requires much deeper commitment from its members to realize its proposals and plans. While ASEAN has always been recognized as the APT's primary driver, it is less likely that ASEAN could remain at the driving seat in the long run thus removing the possibility of ASEAN assuming the leadership position in the APT. As a former senior ASEAN diplomat observed that until today, ASEAN does not drive the APT process as a complete group (Former ASEAN diplomat, personal communication, February 23, 2007). It is a turn-taking driving among only several ASEAN countries that clearly shows the lack of capability (and capacity) of ASEAN as a collective group to drive the process further into the future. Besides, the existing territorial disputes between ASEAN and China, for instance, as well as the regional concerns over terrorism could serve to be a huge stumbling block for ASEAN's effective leadership in the APT. The fact remains; the APT process is at great stake should there be no forthcoming strong leader to anchor the process in the coming years. The possible solution to this dilemma might be to establish a third-party role as a mediator toward the APT process. The ASEM process is one of those possibilities where East Asian countries begin to form and develop its collective identity with the facilitation of the EU as the third party. It then suggests that the APT process has to remain open rather than closed.

\section{CONCLUSION}

Despite the systemic change (downfall of the Soviet Union, the fortress Europe, and the 
failing global multilateral trade talks), the EAEG failed to take off. The various national interests and political concerns had undermined the idea about EAEG. If ASEAN + 3 were to be of any different, that lies in the fact that it came about under different pressure- the Asian Financial crisis. Arguably, such a crisis had led to the need of closer regional cooperation. The crisis, then, served to be the new basis for the region to work on deepening the process of regional integration. On the other hand, basing a regional integration project exclusively on such a crisis could also increase the prospect for failure. A crisis (and the awareness to prevent future crisis) should cautiously make itself to be a basis for an integration process. A crisis could only facilitate (indirectly influence) but not drive the process of integration. Supposed that another financially- or economically-related crisis (which is highly possible) is to occur sometime in the near future, the relevance (at least among some members in the integration process) of ASEAN +3 could be questioned and thus putting the entire process of integration via ASEAN +3 at stake. Therefore, it may facilitate by means of speeding up the process but it should not be the foundation upon which integration process builds itself. East Asia then needs more solid basis to form an integration- a shared motive that probably has to go beyond the rhetoric of pan-Asianism given the heterogeneity of and prevalent realities in the region.

Drawing from the on-going discussion, this work clearly sees the need to develop a alternative theoretical framework in explaining the regional integration project in East Asia. The work, in distancing itself from the main theoretical frameworks, views that the ultimate goal for pursuing regional integration should not be confused with the desirable outcome from the regional integration process itself. While Mattli might be reasonable to question why the UK decided only to join the European Community in the 1960s and not in the 1950s, the answer is of little help in explaining the deepening of the European regional integration project. What the work finds misleading in most of these theoretical analyses of regional integration is the ultimate equation between prosperity and regional integration. That countries are better off together than they are alone. Hence, countries are drawn to regionally integrating themselves in anticipating for a better sum-game. However, as much as the globalization process does not promise more prosperity, so does the regionalization process. Regional integration process requires accountability and commitment from all its participating members to realize its goals and dreams.

It is in this regard that the European model of regional integration needs to be critically assessed before one applies it in other regions namely the East Asia in order to understand the regional integration process. Fundamentally speaking, East Asia, unlike Europe, is not only heterogeneous in terms of its cultural identities, but also in terms of its historical and ideological experiences. While one could argue that the two World Wars were responsible to bind Europe much closer with one another (in preventing such a catastrophe from recurring), East Asia lacks such a similar shared moment in history. The holocaust experience, for example, finds no counterpart in East Asia and even the Japanese atrocities during World War 2 was arguably affecting the entire region (with some parts of the region experiencing more atrocities than the other).

To begin with, the Franco-German relationship hardly likens itself to the Sino-Japanese relationship. The many disastrous wars that had characterized the Franco-German conflict served to be a strong motive for the modern political elites to explore possibilities for a perpetual end to the conflict. This motivation is also shared by other states in Europe especially the smaller ones which had directly suffered from such a conflict between France and Germany. The Sino-Japanese relationship, however, presents an entirely different story. The problematic relationship is arguably recent in its origin compared to that of the Franco-German. It lacks the region-wide effect where the first and second Sino-Japanese conflict revolved around the respective politics of the two states. Southeast Asia, in this case, was very minimally affected by the conflict.

East Asia, unlike Europe, had repeatedly been the outpost theaters for the United States and the Soviet to conduct their ideological conflict. While the research does not suggest 
that the threat of military conflict was real in post-war Europe, the threat never developed into real war or confrontational. However, Asia saw not only real threats but also real wars. The Vietnam War and the Korean Wars were two reasonably global-scale wars that saw the further divide in the region. While the Marshall Plan witnessed the Americans' strong commitment to develop and grow together with Europe, the post-war East Asia, however, saw virtually no such Americans' commitment. Instead, the Japanese were made the pastorchild of Washington while leaving the rest of the region in constant search for its own post-war formula to recover. Hence, one sees today the deep ideological differences practised across the region that makes it difficult to achieve common political goals, let alone collective identity.

The absent factors above underscore the major challenge to apply the European model in East Asia. First, given the regional geo-political structure, political integration in East Asia looks very remote in the near future. This, however, does not mean that it is completely impossible in the future, provided that the current regional integration process is pursued strategically. This underscores the importance to intensify the economic cooperation in the region, as economic motives have remained the only reliable motives for integrating the different states in the region. This work, then, admits the importance of the marketfactor in further intensifying the regional integration process. Nevertheless, cautiously accepting the development of exclusive market-oriented regionalization, the work proposes the open-style regionalization where the region strengthens both its internal and external partnerships. In arithmetical terms, this work is proposing a 'East Asia (APT) + ...' model of regionalization. This proposed model, by all means, requires further empirical investigation that provides a interesting departure for future research on the subject.

In summary, East Asia stands no inferiority to regional integration. Although the region may lack certain qualities that integrate other regions, those absent qualities present different challenges to the regional integration process. It also highlights the need to develop a specific model upon which East Asia can successfully pursue its regional integration project. Of great importance to East Asia is the need to recognize the strengths of the region through which the regional integration project is to be pursued. It does not really matter which type of integration approaches is at play, political, security, or economic, for as long as the process works on the real capabilities of the regional members to achieve reasonable and feasible outcome. The work is extremely critical of any attempt at pursuing too many approaches with ambitious goals. A strategic step-by-step regionalization is probably the best solution to go.

\section{NOTES}

1. The word 'strong' here suggests a substantial institutionalism of a particular regional institution. With regard to ASEAN, its institutionalism is more a tribute to the neo-liberal "zeitgeist" than real substance.

2. Throughout its life, ASEAN's cohesion depended upon a common anti-Communism cause. This shared raison d'être among all ASEAN members (the then original six members) had brought about common policy stance namely on the Cambodian issue.

3. It should be note, however, that NAFTA adopts a open-style regionalism which does not discriminate members and non-members. Nevertheless, many leaders, especially in the developing countries, cautiously buy this argument. For one thing, the US participation (and to a certain extent Canada), given its status as global economic Power, could still impose discriminative measures against other countries outside NAFTA when necessary situations arise to do so.

4. It is still speculative to suggest that the U.S. would accept the idea had the proposal included the U.S. (together with Australia and New Zealand). The EAEG might render 
itself redundant in the presence of APEC. Furthermore, it would be completely complicated to think how would Mahathir assign the leadership role to the 'big' Powers if too many of them were included in EAEG.

5. This, to me, reflects the weak institutionalized nature of ASEAN. It would generally difficult for a revolutionary idea like EAEG to be discussed and got voted for in ASEAN, at least at that time. After all ASEAN's endorsement might have weighted less in guaranteeing its survival for real implementation. Mahathir, then, was looking for acceptance (hence implementation) rather than opinion.

6. Framing the current discussion in a more present-day context, possible reactions are to be observed following Japan's recent move to actively participate in military operations (for reconstructions and rescue works) in collaboration with NATO. The re-establishment of the Japan's Defense Ministry suggests Japan's expressed intention to develop its military capability. While Japan's move could logically be understood as self-defense, historically understanding may lead its immediate neighbors to interpret the current development rather offensively.

7. Economies across the region experienced varying impact of the crisis. Indonesia, South Korea, and Thailand were the economies most affected by the crisis. Hong Kong, Malaysia, Laos, and the Philippines were also hit by the slump. Mainland China, Taiwan, Singapore, and Vietnam were relatively unaffected. Japan was not affected much by this crisis but was going through its own long-term economic difficulties. However, all these economies mentioned above saw their currencies dip significantly relative to the US dollar, though the harder hit economies saw extended currency losses. Out of all these economies, South Korea was hit hardest.

8. The US economy recovered from its economic recession in the middle of 1990s by increasing the federal interest rates to attract new investments. This had two implications for many economies in East Asia. First, their economies became less attractive to foreign investors relative to that of the United States. Second, it raised the value of foreign debts of these East Asian economies as most of them ran a close currency-peg to the US dollar and therefore most of these debts were denominated in US dollar. The latter implication also tied up itself to other controversial macro-economic policies on market information management as well as transparency in corporate governance.

9. The first APT summit was, in fact, a pure coincidence. The absence of some major leaders namely Suharto and Kim Young Sum at the summit made it less credible to even significantly discuss the financial crisis. As a result, the first APT summit was not at all clear whether or not it existed because of the crisis. See Tanaka Akihiko, "The Development of ASEAN + 3," 7. It, however, did serve as a strong cause for keeping the APT process alive.

10. By this time, ASEAN was very thankful, at least to China and Japan, for maintaining their friendship. ASEAN appreciated China's decision not to devalue its yuan at the time when the crisis-hit Southeast Asian countries were just about to rebuild their economy after the crisis. Japan, on the other hand, had provided some USD30 billion under the Miyazawa Plan to help adversely affected Southeast Asian countries.

11. China is also actively involved in this new wave. Following the proposal of the former Philippine's President Ramos, China plays a leading role in the Boao Forum for Asia (BFA), a non-governmental and not-for-profit international organization modeled after the World Economic Forum in Davos, Switzerland. This forum discusses Asian economic community issues and regional cooperation in investment, tariffs, and finance. It was noted that despite its non-governmental consultative body status, the forum did discuss the necessity of a unified response by Asia against the Western economic power and the 
China's leadership role in Asia's collective response to the West. See Ibid.

12. In principle, the Chiang Mai Initiative was proposed and agreed upon during the APT's finance minister meeting on May 6, 2000 in Chiang Mai before it was endorsed by the summit meeting. The initiative is an international arrangement that works similarly like that of the IMF's emergency credit. It attempts to prevent the future financial crisis like the Asian financial crisis (to control the damaging effects of future financial crisis).

13. This study group comprised of government officials who discussed ways to develop the APT process into a regional cooperative forum. It assessed the EAGV's recommendations and submitted its report in 2002. The group identified 17 concrete short-term measures and nine medium-to-long-term measures to move East Asian cooperation significantly forward. Leaders agreed with the Republic of Korea's vision for APT summits to evolve in the long term into East Asian summits and eventually an East Asian Free Trade Area.

Table 1

Appendix A

Top Two Trading Partners Of Selected East Asian Countries

\begin{tabular}{|c|c|c|c|c|c|c|c|c|c|c|}
\hline TRADING PARTNERS & $\frac{\pi}{\mathbb{Z}}$ & 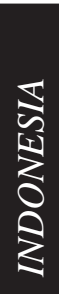 & 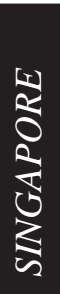 & $\begin{array}{l}\mathbb{J} \\
\frac{\pi}{5} \\
\mathbb{Z}\end{array}$ & $\begin{array}{l}\bar{T} \\
\text { ஸे }\end{array}$ & $\begin{array}{l}\stackrel{\vartheta}{Z} \\
\mathbb{Z} \\
\underset{\mathbb{Z}}{\mathbb{Z}}\end{array}$ & $\underset{\mathbb{Z}}{\stackrel{\mathbb{Z}}{\mathbb{Z}}}$ & $\underset{\mathbb{J}}{\mathbb{Z}}$ & 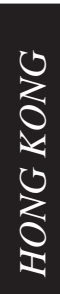 & 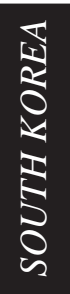 \\
\hline \multirow{2}{*}{ BRUNEI } & & & $X$ & $X$ & & & & & & \\
\hline & $X$ & $X$ & & & & & & & & \\
\hline \multirow{2}{*}{ MALAYSIA } & $X$ & & & & $X$ & & & & & \\
\hline & & & $X$ & & $X$ & & & & & \\
\hline \multirow{2}{*}{ CAMBODIA } & & & & & & $X$ & & $X$ & & \\
\hline & & & & & & $X$ & $X$ & & & \\
\hline \multirow{2}{*}{ SINGAPORE } & & & & $X$ & $X$ & & & & & \\
\hline & & & & $X$ & $X$ & & & & & \\
\hline \multirow{2}{*}{ THAILAND } & $X$ & & & & & & & $X$ & & \\
\hline & $X$ & & & & $X$ & & & & & \\
\hline \multirow{2}{*}{ CHINA } & $X$ & & & & & & & & & $X$ \\
\hline & & & & & $X$ & & & & $X$ & \\
\hline \multirow{2}{*}{ JAPAN } & & & & & $X$ & & & $X$ & & \\
\hline & & & & & $X$ & & & $X$ & & \\
\hline SOUTH KOREA & $X$ & & & & $X$ & & & \begin{tabular}{|l}
$X$ \\
$X$
\end{tabular} & & \\
\hline
\end{tabular}

source: CIA Factbook 2007 
Table 2

APPENDIX B

US - China Trade Balance (1989 - 2006) ${ }^{1}$

\begin{tabular}{|c|c|}
\hline Year & Trade Balance $^{2}$ \\
\hline 1989 & -6234.3 \\
\hline 1990 & -10431 \\
\hline 1991 & -12691 \\
\hline 1992 & -18309 \\
\hline 1993 & -22777 \\
\hline 1994 & -29505.1 \\
\hline 1995 & -33789.5 \\
\hline 1996 & -39520.2 \\
\hline 1997 & -49695.5 \\
\hline 1998 & -56927.4 \\
\hline 1999 & -68677.1 \\
\hline 2000 & -83833 \\
\hline 2001 & -83096.1 \\
\hline 2002 & -103064.9 \\
\hline 2003 & -124068.2 \\
\hline 2004 & -161938 \\
\hline 2005 & -201544.8 \\
\hline 2006 & -232588.6 \\
\hline & \\
\hline
\end{tabular}

notes:

1 this trade balance excludes trade in services

2 in million USD

3 the negative '-' signifies deficit for the U.S.A.

source: U.S. Census Bureau, Foreign Trade Division

\section{REFERENCES}

ADB. Foreign Direct Investment Spurs Asia's Development. News Release. Retrieved June 1, 2007, from http://www.adb.org/Documents/News/1999/nr1999024.asp APEC has run out of steam, says New Zealand. (2000, June 30). Financial Times.

ASEAN Secretariat. (2002, November 4). Press Statement of by the Chairman of the 8th ASEAN Summit, the 6th ASEAN + 3 Summit, and the ASEAN - China Summit. Retrieved June 30, 2007, from http://www.aseansec.org/13188.htm (30 June 2007).

BAOGANG, H. (2004, March). East Asian ideas of regionalism: a normative critique. Australian Journal of International Affairs, 58(1), 115.

BERGSTEN, F (1995). The Bogor Declaration and the Path Ahead. In Sakong, I. and Lee, J. (Eds.), Asia-Pacific Economic Cooperation under the WTO System (pp. 13-25). Soeul, Korea: Institute of East and West Studies, Yonsei University.

CHIRATHIVAT, S. (2005). The ASEAN Perspective on East Asian-wide Regionalism. In Harvie Fukunari Kimura, and Hyun-Hoon Lee (Eds.), New East Asian Regionalism: Causes,Progress and Country Perspectives (pp. 149-170). Cheltenham, United Kingdom: Edward Elgar Publishing Limited.

DE MELO, J.AND PANAGARIYA A. (1993). New Dimensions in Regional Integration. Cambridge: Cambridge University Press.

GUOHUA, P. AND ZHANG, X. (2002). Dongya diquehezuo yu hezuojizhi (Regional Cooperationand Mechanism in East Asia). Beijing: Central Compliance and Translation Press.

HAPPY NEIGHBOURS. (2000, August 26) The Economist, 71. 